\title{
Genetic bottlenecks in Turkish okra germplasm and utility of iPBS retrotransposon markers for genetic diversity assessment
}

\author{
M. Yıldız', M. Koçak ${ }^{1}$ and F.S. Baloch ${ }^{2}$ \\ ${ }^{1}$ Department of Agricultural Biotechnology, Faculty of Agriculture, \\ Yuzuncu Yil University, Van, Turkey \\ 2Department of Field Crops, Faculty of Agricultural and Natural Science, \\ Abant Izzet Baysal University, Bolu, Turkey \\ Corresponding author: M. Yıldız \\ E-mail: myildiz@yyu.edu.tr
}

Genet. Mol. Res. 14 (3): 10588-10602 (2015)

Received June 2, 2015

Accepted August 26, 2015

Published September 8, 2015

DOI http://dx.doi.org/10.4238/2015.September.8.20

\begin{abstract}
Lack of requisite genetic variation in Turkish okra has necessitated the use of different types of markers for estimating the genetic diversity and identifying the source of variation. Transposable elements, present abundantly in plant genomes, generate genomic diversity through their replication and are thus an excellent source of molecular markers. We hypothesized that inter-primer binding site (iPBS)-retrotransposons could be the source of variation because of their genome plasticity nature. In the present study, genetic diversity of 66 okra landraces was analyzed using iPBS-retrotransposon markers. iPBS-retrotransposons detected 88 bands with $40.2 \%$ polymorphism and an average of 6.8 bands per primer. Gene diversity and Shannon's information index ranged from 0.01 to 0.13 and 0.02 to 0.21 for iPBS-retrotransposons and from 0.06 to 0.46 and 0.14 to 0.65 for simple sequence repeat (SSR) markers, respectively. Polymorphism information content value for retrotransposons varied between 0.12 and 0.99 , while that for SSR was from 0.52 to 0.81 . Neighbor joining analysis based on retrotransposons and SSRs divided all the accessions into
\end{abstract}


four clusters; however, SSR markers were more efficient in clustering the landraces based on their origin. Using the STRUCTURE software for determining population structure, and two populations (at the number of hypothetical subpopulations, $\mathrm{K}=2$ ) were identified among the landraces. Low genetic diversity in Turkish okra highlights the need for the introduction of plants from countries with greater genetic diversity for these crops. This study also demonstrates the utility and role of iPBS-retrotransposons, a dominant and ubiquitous part of eukaryotic genomes, for diversity studies in okra.

Key words: Population structure; Abelmoschus esculentus; Genetic diversity; Retrotransposons; Turkish landraces

\section{INTRODUCTION}

Okra [Abelmoschus esculentus (L.) Moench], also called lady's finger, is an important vegetable crop of Asia, Mediterranean region, and Africa. It is an allopolyploid crop with considerable variation in the chromosome number $(2 n=72-144)$ and ploidy levels. Geographical origin of okra is disputed, with support existing for probable origins in South Asia, Ethiopia, and West Africa (Düzyaman, 1997). Several previous researchers have proposed that the origin of cultivated okra may be polyphyletic rather than being from a single species. West Africa was considered as its place of origin because of the existence of related wild species in the Nile Valley and Ethiopia (De Candolle, 1886). Other researchers (Bates, 1968) reported that okra originated in South and Southeast Asia mainly because wild relatives abound there. Mediterranean, near east and Southern USA are considered to be secondary centers of diversity, where introduction and selection enabled adaptation to the agro-climatic conditions of those regions (Grubben, 1977). Okra is valued for its edible green seed pods. It is a good source of protein and carbohydrate, dietary fiber, minerals, like iron, calcium, manganese and magnesium, vitamins $\mathrm{A}, \mathrm{B}, \mathrm{C}$, and $\mathrm{K}$, as well as folates, and contains very high levels of antioxidants such as xanthin and lutein.

Historically, more than $99 \%$ of the worldwide okra cultivation has been localized in the developing countries of Asia and Africa where funding for genetic research is scarce, and there is paucity in the development and implementation of molecular techniques in okra breeding in comparison to that available for other major crop species (Schafleitner et al., 2013). Okra is considered a minor crop, and until recently, little attention has been paid to its genetic improvement. Despite being an important vegetable for centuries, very little effort has been devoted to the genetic studies and gene mapping of this crop.

Characterization of the population structure of the okra germplasm has been initiated. However, detailed analyses of regional- or country-specific differences are lacking and have only recently been undertaken in some countries. Endowed with a wealth of biodiversity, Turkey could be an excellent place to study country-specific differences in the okra germplasm. However, Turkey has not been the center of origin or diversity for okra. To date, only a few studies have been conducted using the Turkish okra germplasm (Martin et al., 1981; Düzyaman and Vural, 2002). Sequence related amplified polymorphism (SRAP) analysis was performed on 21 Turkish and 2 USA originated okra genotypes (Gulsen et al., 2007).

The cultivated species, $A$. esculentus, is a cultigen of the tropical and sub-tropical low altitude regions in Asia, Africa, and America, extending to the temperate regions of the 
Mediterranean basin (Charrier, 1984). Okra genotypes in Greece are considered to have been almost exclusively derived from Turkish cultivars, but to what extent the migration of Turkish genotypes into Greece occurred via land (through Thrace and Macedonia) or the Aegean islands is unknown (Kyriakopoulou et al., 2014). In Turkey, okra research and breeding activities were initiated at Yalova Atatürk Bahçe Kültürleri Research Institute (Düzyaman, 1997). Until 1986, the institute mainly concentrated on regional issues of okra cultivation. Many okra varieties have been introduced in Turkey from different countries, specifically targeting the yield and quality preferred by local farmers and consumers.

Being a minor crop, cultivated only on small scales, okra has marginal importance for Turkish agriculture. Okra is grown on small farms in almost all regions of Turkey, as well as they are commercially cultivated in Mediterranean, Marmara, central Anatolian, and Aegean region of Turkey. There are many locally named varieties and landraces of okra in Turkey. Since 1970, okra landraces have been collected from all over Turkey and have been preserved in the gene bank of the Aegean Agricultural Research Institute. The origin of okra in Turkey is poorly understood. Turkish okra is debated to be a composite of multiple introductions from the African continent to the Anatolian plateau by the Arabs in ancient times because of morphologic similarities between the Turkish okra accessions and the African germplasm (Düzyaman, 2009). A unique aspect of okra consumption in Turkey is the preference for extremely small pods unlike that for bigger pods in other okra producing countries (Düzyaman, 2009). The reason for this difference is that as the pods of Turkish genotypes increase in size, they become intensely fibrous and progressively inedible (Iremiren et al., 1991), whereas those of the American cultivars, for example, remain tender to a greater size.

Genetic diversity is important for selection of parents to recover transgressive segregants (Baloch et al., 2015a). In many crops, including okra, continuous cycles of controlled breeding over thousands of years have led to narrow genetic backgrounds. To identify genetic diversity and DNA profiles of okra, several DNA marker systems such as SRAP (Gulsen et al., 2007), random amplified polymorphic DNA (RAPD; Aladele et al., 2008; Nwangburuka et al., 2011; Prakash et al., 2011), simple sequence repeat (SSR; Sawadogo et al., 2009; Schafleitner et al., 2013), and amplified fragment length polymorphism (AFLP; Kyriakopoulou et al., 2014) have been employed.

Among the various DNA markers, retrotransposon markers have been widely applied in numerous evolutionary and genetic studies due to their general applicability, simplicity of implementation, and genotype resolution systems. Retrotransposons represent one of the most changing genomic elements whose copy numbers have varied considerably over short evolutionary periods and thus, could be significant components of the structural evolution of plant genomes. Retrotransposons are abundant throughout the genomes of all eukaryotes especially plants (Finnegan, 1989). Genomes of plant species differ in their retrotranposon content, which often constitutes $50 \%$ of the plant genome but could be as high as $90 \%$ (San Miguel et al., 1996). Their abundance and ability to amplify and insert themselves throughout the genome make them powerful DNA markers for divergent populations in different groups of organisms (Zampicinini et al., 2004). The inter-primer binding site (iPBS) method is a proven powerful DNA fingerprinting technique which obviates the need for previous knowledge about a sequence. The iPBSretrotransposon DNA marker system is referred to as the "universal marker system" because it is the only retrotransposon-based marker system that has allowed for visualization of polymorphism throughout the plant and animal kingdom.

Previously, this system has successfully been employed in evaluating the genetic diversity in grapes (Guo et al., 2014), apricot (Baránek et al., 2012), Cicer (Andeden et al., 2013), cultivated and wild Lens species (Baloch et al., 2015a), and field pea (Baloch et al., 2015b). iPBS- 
retrotransposon markers have not yet been used for genetic diversity studies in okra. Previous studies (Gulsen et al., 2007; Yildiz M, Ekbiç IE, Duzyaman E, Serçe S, et al., unpublished results) have demonstrated very narrow genetic diversity in Turkish okra germplasm based on evaluation using different molecular markers. Therefore, we endeavored to check the application of iPBSretrotransposon markers in detecting the genetic diversity in okra germplasm used in breeding programs by many researchers. The specific objectives of the present study were as follows: 1) to check the utility of iPBS-retrotransposon markers for phylogenetic analysis in okra gemplasm, 2) to evaluate the population structure of Turkish okra varieties based on iPBS-retrotransposon markers, 3) to detect variations between iPBS-retrotransposon data and that obtained using some SSR markers in order to determine the degree of similarity in the relationships predicted by each method, and 4) to explore the Turkish okra breeding patterns by examining the genetic relationships of Turkish and foreign varieties commonly used in the Turkish okra breeding program.

\section{MATERIAL AND METHODS}

\section{Plant material and DNA extraction}

Sixty-six okra accessions, including 39 from Turkey, 9 from India, 11 from the United States, 5 from Africa, and 2 from Japan were used in this study. The variety name, place of collection in Turkey, origin, and source of each accession is described in Table 1. The Turkish accessions were regarded as the possible local landraces available from Turkey.

Ten seeds from each cultivar were grown in pots and minimum of five individuals (five weeks old) per accession were sampled in bulk, and lyophilized for DNA extraction. Total genomic DNA was extracted following a modified CTAB method (Boiteux et al., 1999). Subsequently, DNA concentration was measured with NanoDrop 2000 (ThermoScientific, Wilmington, DE, USA) and was adjusted to $50 \mathrm{ng} / \mu \mathrm{L}$ for use in polymerase chain reaction (PCR).

\section{iPBS-retrotransposon analysis}

A total of 83 recently developed iPBS-retrotransposon primers were initially screened on 8 randomly selected okra cultivars to determine the polymorphism status of the primers (Kalendar et al., 2010). Thirteen iPBS-retrotransposon primers, which produced excellent banding profiles, were selected for fingerprinting the entire set of landraces and cultivars. The name of primers, their sequence, and annealing temperature are provided in Table 2. PCR amplifications were performed in Veriti 96-well Veriti-Thermal Cycler (Applied Biosystems, Foster City, CA, USA). A 25- $\mu \mathrm{L}$ PCR mixture contained $50 \mathrm{ng}$ template DNA, 1X Dream Taq Green Buffer (Fermentas, USA), $0.2 \mathrm{mM}$ dNTPs (Fermentas), primers [1 $\mu \mathrm{M}$ 12- to 13-nucleotide (nt)-long primers or $0.6 \mu \mathrm{M}$ of 18-ntlong primers], $1 \mathrm{U}$ Dream Taq DNA polymerase (Fermentas), and 0.04 U PFu DNA polymerase (Fermentas; Kalendar et al., 2010). The PCR conditions were as follows: initial denaturation at $95^{\circ} \mathrm{C}$ for $3 \mathrm{~min} ; 30$ cycles at $95^{\circ} \mathrm{C}$ for $15 \mathrm{~s}, 50^{\circ}-65^{\circ} \mathrm{C}$ (annealing temperature, depending on the primers used) for $1 \mathrm{~min}$, and $68^{\circ} \mathrm{C}$ for $1 \mathrm{~min}$; and final extension at $72^{\circ} \mathrm{C}$ for $5 \mathrm{~min}$ (Kalendar et al., 2010). PCR products were separated by electrophoresison a $1.7 \%(\mathrm{w} / \mathrm{v})$ agarose gel using $0.5 \mathrm{X}$ TAE buffer for $3 \mathrm{~h}$; the gel was stained with ethidium bromide, and visualized under a UV transilluminator (Quantum ST4, Vilber Lourmat, France). A 200-bp ladder (Fermentas) was used as a molecular weight marker. 


\begin{tabular}{|c|c|c|c|c|c|}
\hline Accession & Geographical province & Source & Accession & Origin & Source \\
\hline Turkey & & & America & & \\
\hline TR-01-1 & Adana & $\mathrm{PC}^{\mathrm{b}}$ & Cajun Queen & & Di.Va.P.R.A. ${ }^{e}$ \\
\hline TR-01-2 & Adana & PC & Dixie Spineless & & Di.Va.P.R.A. \\
\hline TR-01-3 & Adana & $\mathrm{PC}$ & DLGG & & Di.Va.P.R.A. \\
\hline TR-01-4 & Adana & PC & Emerald & & San Martin Seeds \\
\hline TR-05-1 (TR48520) & Amasya & $\mathrm{AARI}^{\mathrm{c}}$ & Jade & & Arkansas Univ. \\
\hline TR-05-2 & Amasya & $\mathrm{ACHRI}^{\mathrm{d}}$ & Jefferson & & Arkansas Univ. \\
\hline TR-10-1 & Balıkesir & $\mathrm{PC}$ & Lee & & Di.Va.P.R.A. \\
\hline TR-10-2 & Balıkesir & ACHRI & UGA Red Okra & & Georgia Univ. \\
\hline TR-15-1 & Burdur & ACHRI & Perkins Spineless & & Asgrow \\
\hline TR-17-1 (TR 43092) & Çanakkale & AARI & Red Wonder & & Di.Va.P.R.A. \\
\hline TR-17-2 (TR 43099) & Çanakkale & AARI & Okra Brazil & & Di.Va.P.R.A. \\
\hline TR-20-1 & Denizli & $\mathrm{PC}$ & & & \\
\hline TR-20-2 & Denizli & ACHRI & Africa & & \\
\hline TR-20-3 & Denizli & ACHRI & 803 Burkina Faso & Burkina Faso & IBPGR $^{f}$ \\
\hline TR-27-1 (TR 40293) & Gaziantep & AARI & 1051 Togo & Togo & IBPGR \\
\hline TR-33-1 & Mersin & PC & 1159 Togo & Togo & IBPGR \\
\hline TR-33-2 & Mersin & PC & 2163 Sudan & Sudan & IBPGR \\
\hline TR-35-1 (TR 57346) & İzmir & AARI & Red Balady & Egypt & Ain Shams Univ. \\
\hline TR-35-2 & İzmir & $\mathrm{PC}$ & & & \\
\hline TR-37-1 (TR 51605) & Kastamonu & AARI & India & & \\
\hline TR-42-1 (TR 69231) & Konya & AARI & Arka Anamika & & Maharashtra Seed \\
\hline TR-47-1 (TR 35291) & Mardin & AARI & Pakistana & & Di.Va.P.R.A. \\
\hline TR-48-1 (TR 61730) & Muğla & AARI & Parbhani Kranti & & ICRISAT' \\
\hline TR-48-2 & Muğla & $\mathrm{PC}$ & Pusa Makhamali & & Di.Va.P.R.A. \\
\hline TR-54-1 (TR 68542) & Sakarya & AARI & Pusa Sawani & & Di.Va.P.R.A. \\
\hline TR-55-1 & Samsun & AARI & PSM & & Di.Va.P.R.A. \\
\hline TR-60-1 (TR 51691) & Tokat & AARI & Selection-2 & & NBPGR ${ }^{\mathrm{h}}$ \\
\hline TR-63-1 & Şanlıurfa & PC & $\mathrm{T}-13$ & & Di.Va.P.R.A. \\
\hline TR-63-2 & Şanlıurfa & PC & Vaishali Badhu & & Di.Va.P.R.A. \\
\hline TR-63-3 & Şanlıurfa & PC & & & \\
\hline TR-64-1 (TR 66581) & Uşak & AARI & Japan & & \\
\hline TR-68-1 (TR 69234) & Aksaray & AARI & Holiday & & Gunma Prefecture \\
\hline TR-70-1 (TR 69229) & Karaman & AARI & Japan & & Hyogo Prefecture \\
\hline TR-77-1 & Unknown & $\mathrm{ACHRI}$ & & & \\
\hline TR-Co-1 & Marmara & Commercial & & & \\
\hline TR-Co-2 & Sultani & Commercial & & & \\
\hline TR-Co-3 & Sultani & Commercial & & & \\
\hline TR-Co-4 & Karaburun & Commercial & & & \\
\hline Cyprus & Cyprus & & & & \\
\hline
\end{tabular}

Tripartite designation is for accession, abbreviation of country (for Turkey), plate number of the province and numbered according to the order of collection, respectively. ${ }^{\mathrm{DPC}}$; personal collection. ' ${ }^{\mathrm{A}}$ egean Agricultural Research Institute. ${ }^{\mathrm{d} A t a t u r k}$ Central Horticultural Research Institute. ${ }^{e}$ Department of Exploitation and of Agricultural and Forestry Resources. fInternational Board for Plant Genetic Resources. International Crops Research Institute for the Semi-Arid Tropics. nNational Bureau of Plant Genetic Resources.

\section{SSR analysis}

Nine SSR primers with binding sites covering the entire okra genome were selected from previously published results (Schafleitner et al., 2013). PCRs were performed in a total volume of $20 \mu \mathrm{L}$ containing $30 \mathrm{ng}$ template DNA, 1X PCR buffer, $0.2 \mathrm{mM}$ dNTPs, $0.5 \mathrm{pM}$ of each primer, and $0.1 \mathrm{U}$ Taq polymerase (Fermentas). The thermocycler was programmed as follows: initial cycle at $95^{\circ} \mathrm{C}$ for $10 \mathrm{~min}$, followed by 35 cycles at $94^{\circ} \mathrm{C}$ for $30 \mathrm{~s}, 55^{\circ} \mathrm{C}$ for $45 \mathrm{~s}$, and $72^{\circ} \mathrm{C}$ for $45 \mathrm{~s}$, followed by a final extension at $72^{\circ} \mathrm{C}$ for $5 \mathrm{~min}$ (Schafleitner et al., 2013). Amplicons were size-fractionatedon a $3 \%(\mathrm{w} / \mathrm{v})$ high-resolution agarose gel (Gene Pure HiRes Agarose, ISC Bioexpress, Kaysville, UT, USA) for $5 \mathrm{~h}$ in 0.5X TAE buffer, and visualized by ethidium bromide staining. A 200-bp ladder (Fermentas) was used as a molecular weight marker. 


\section{Data analysis}

Reproducibility of DNA profiles for retrotransposon marker systems was tested by repeating two times of the PCR amplification with each of the primers selected. Only clear and intense bands were considered for analyses. The iPBS-retrotransposon bands were assigned a score of 1 or 0 , using the binary scoring system based on the presence or absence of bands, respectively. The SSR amplicons were also scored in the binary fashion and used for data analysis. Shannon's information index, gene diversity, and number of effective alleles among cultivars with SSR and iPBS-retrotransposon markers were calculated using the POPGENE ver. 1.32 software (Yeh et al., 2000). The polymorphism information content (PIC) was calculated using the previously reported formula (De Riek et al., 2001):

$$
\mathrm{PIC}_{i}=2 f_{i}\left(1-f_{i}\right)
$$

where, $f_{i}$ is the frequency of the amplified allele (band, present) and $\left(1-f_{i}\right)$ is the frequency of the null allele (band, absent) of the marker. Genetic distance coefficients among okra accessions was estimated according to Jaccard index (Jaccard, 1908) for pairwise comparison based on the proportion of shared bands produced by all primers. Neighbor joining analyses were constructed using the R computer statistical software.

\section{Population structure analysis}

Population structure and inference of admixture ancestry were assessed with a model-based clustering method, implemented using the STRUCTURE 2.1 software. In this program, the number of hypothetical subpopulations $(\mathrm{K})$ was assumed; each was characterized by a set of allele frequencies at a particular locus. The number of $\mathrm{K}$ selected was 1 to 10 based on models characterized by admixed and correlated allele frequencies. Different $K$ values were tested (from 1 to 10 ) with ten independent runs for each value (50,000 Burn-in periods and 150,000 Monte Carlo Markov Chain; Evanno et al., 2005). The change in the log probability of data between successive $\mathrm{K}$ values obtained from the STRUCTURE output was used to determine the true number of subpopulations (Figure 1). Subpopulations were assembled by groupings' accessions with a membership probability higher than 0.70 , while accessions with a lower membership probability were assigned to a mixed group.

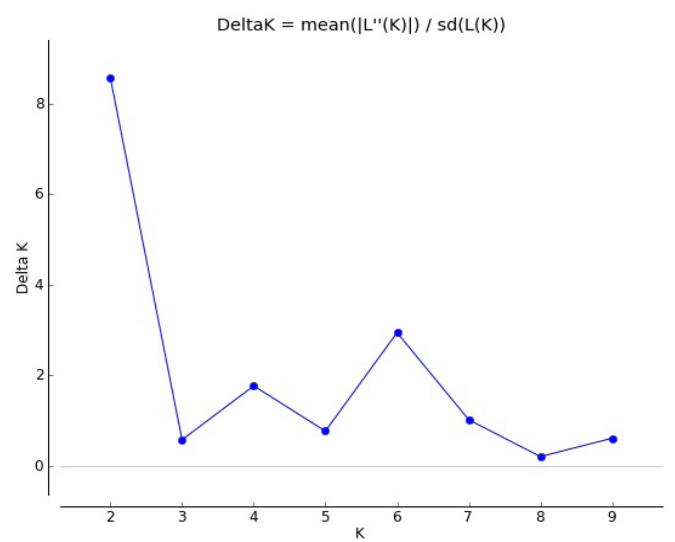

Figure 1. Estimated $\mathrm{K}$ value for the structure analysis of okra germplasm used in the study. 


\section{RESULTS}

\section{Retrotransposon diversity}

Eighty-three iPBS primers were screened among 8 randomly selected okra varieties. No PCR product was obtained for 43 iPBS primers, whereas 28 primers gave amplification with monomorphic banding pattern, and 13 primers produced PCR product with polymorphism. The 13 primers yielding clear and reproducible banding profiles were selected for further analysis. These primers produced 88 scorable bands, of which 53 were monomorphic and 35 were polymorphic. The number of retrotransposon bands per primer varied from 3 (for primers RT2395 and RT2251) to 14 (for primer RT2231), with an average of 6.8 bands per primer (Table 2). The maximum number of polymorphic bands (9 bands) was obtained using the RTR2231 primer, while the minimum number of polymorphic bands ( 1 band) was recorded with 5 retrotransposon primers RT2398, RT2415, RT2395, RT2081, and RT2239; the average number of polymorphic bands per primer was 2.7 (Table 2). The polymorphism percentage ranged from 11.1 to $80 \%$ with an average polymorphism of $40.2 \%$ across all varieties. Gene diversity ranged from 0.01 (for RTR2395, RT2239, and RT2251) to 0.13 (for RTR2231 and RT2080), with a mean value of 0.07 among all cultivars. The mean Shannon's information index ranged from 0.02 (for RTR2239) to 0.21 (for RTR2231). The average PIC value was 0.66 for all retrotransposon primers, and it ranged from 0.12 (for RT2415) to 0.99 (for RT2395, RT2239, RT2274, and RT2251 primers; Table 2).

Table 2. Primer names, their sequences, annealing temperatures, total number of amplified and polymorphic bands, and some diversity parameters of iPBS retrotransposons primers, used in the study.

\begin{tabular}{|c|c|c|c|c|c|c|c|c|c|}
\hline Locus & Sequence & $\mathrm{At}^{*}$ & $\mathrm{~T}^{*}$ & $\mathrm{P}^{*}$ & $\mathrm{P} \%$ & $N_{\mathrm{E}}^{*}$ & $\mathrm{~h}^{*}$ & $1^{*}$ & PIC \\
\hline 2231 & ACTTGGATGCTGATACCA & 52 & 14 & 9 & 64.3 & 1.19 & 0.13 & 0.21 & 0.75 \\
\hline 2295 & AGAACGGCTCTGATACCA & 53 & 6 & 4 & 66.7 & 1.13 & 0.10 & 0.17 & 0.57 \\
\hline 2398 & GAACCCTTGCCGATACCA & 51 & 7 & 1 & 14.3 & 1.07 & 0.05 & 0.07 & 0.33 \\
\hline 2415 & CATCGTAGGTGGGCGCCA & 60 & 8 & 1 & 12.5 & 1.02 & 0.02 & 0.03 & 0.12 \\
\hline 2078 & GCGGAGTCGCCA & 63 & 8 & 2 & 25.0 & 1.02 & 0.02 & 0.04 & 0.53 \\
\hline 2298 & AGAAGAGCTCTGATACCA & 60 & 10 & 5 & 50.0 & 1.20 & 0.11 & 0.18 & 0.55 \\
\hline 2395 & TCCCCAGCGGAGTCGCCA & 53 & 3 & 1 & 33.3 & 1.01 & 0.01 & 0.03 & 0.99 \\
\hline 2080 & CAGACGGCGCCA & 63 & 6 & 2 & 33.3 & 1.22 & 0.13 & 0.19 & 0.48 \\
\hline 2081 & GCAACGGCGCCA & 65 & 9 & 1 & 11.1 & 1.06 & 0.04 & 0.06 & 0.36 \\
\hline 2239 & ACCTAGGCTCGGATGCCA & 55 & 4 & 1 & 25.0 & 1.01 & 0.01 & 0.02 & 0.99 \\
\hline 2244 & GGAAGGCTCTGATTACCA & 50 & 5 & 4 & 80.0 & 1.14 & 0.10 & 0.18 & 0.98 \\
\hline 2274 & GCTCTGATACCA & 65 & 5 & 2 & 40.0 & 1.04 & 0.04 & 0.08 & 0.99 \\
\hline 2251 & GAACAGGCGATGATACCA & 53 & 3 & 2 & 66.7 & 1.01 & 0.01 & 0.03 & 0.99 \\
\hline Total & & & 88 & 35 & - & - & - & - & - \\
\hline Mean & & & 6.8 & 2.7 & 40.2 & 1.10 & 0.07 & 0.12 & 0.66 \\
\hline
\end{tabular}

*At, Annealing temperature; T, total bands; P, polymorphic bands; $N_{\mathrm{E}}$, effective number of alleles (Kimura and Crow, 1964); h, Nei's (1973) gene diversity; I, Shannon's information index (Lewontin, 1972); PIC, polymorphism information contents.

A pairwise genetic distance (GDj) matrix was calculated based on Jaccard's coefficient using the R statistical software. The lowest genetic distance (0.000) was observed among pair of accessions TR48-1-TR63-2, TR70-1-TR63-3, TR37-1-TR15-1, TRCo-3-DLGG, Pusa Sawani-Arka Anamika, while the highest was noted in Red Balady-TR54-1 (0.264) and Red Balady-TR05-2 (0.246) based on iPBS-retrotransposon analysis. Neighbor-joining tree was computed from Jaccard's genetic distance coefficient (Figure 2). The analysis separated the 66 okra accessions 
into four different groups. The number of okra accessions in split A, B, C, and D were 4, 11, 24, and 27 , respectively. Each group was further divided into different subgroups.

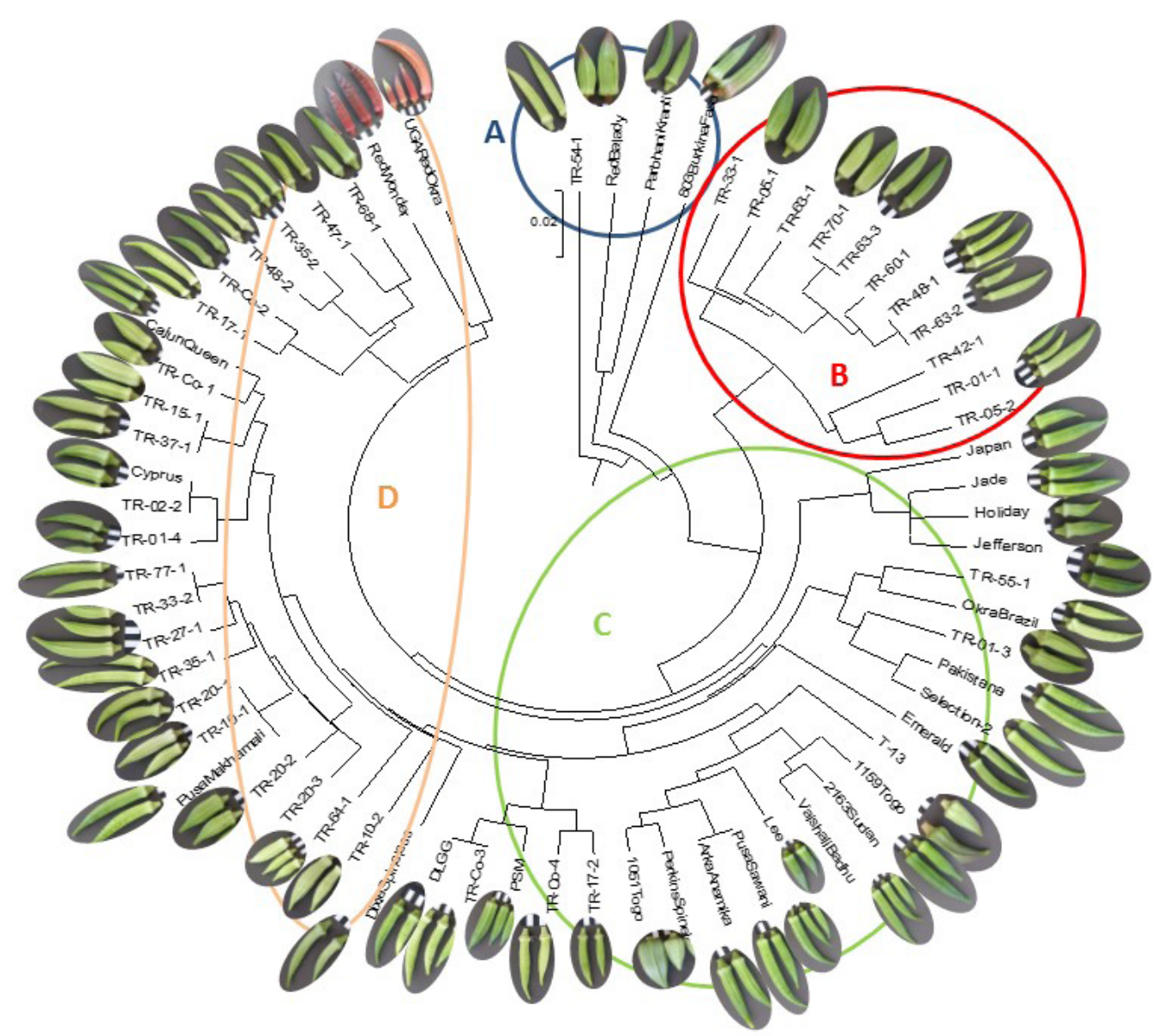

Figure 2. Neighbor-joining analysis of 66 okra landraces and cultivars based on iPBS retrotransposons markers.

\section{SSR diversity}

Nine SSR markers were used to fingerprint all the okra varieties. Twenty-one bands were detected at 9 polymorphic microsatellite markers among 66 okra varieties (Table 3). All SSR markers used in this study produced 2 alleles except SSR52 and SSR64 which produced 4 and 3 alleles, respectively. An average of 2.33 alleles was produced across 9 loci (Table 3). The size of amplified products ranged from $80 \mathrm{bp}$ (for SSR54) to $500 \mathrm{bp}$ (for SSR63). 
Table 3. Primer names, their sequences, annealing temperatures, number of amplified and polymorphic bands, and some diversity parameters of SSR primers used in the study.

\begin{tabular}{|c|c|c|c|c|c|c|c|c|c|c|}
\hline Locus & Sequence & $\mathrm{At}^{*}$ & $\mathrm{~T}^{*}$ & $\mathrm{P}^{*}$ & $\mathrm{P} \%$ & $N_{\mathrm{E}}{ }^{*}$ & $\mathrm{~h}^{*}$ & $I^{*}$ & $\mathrm{Ht}^{*}$ & $\mathrm{PIC}^{*}$ \\
\hline SSR9 & $\begin{array}{l}\text { F: ACCTTGAACACCAGGTACAG } \\
\text { R: TTGCTCTTATGAAGCAGTGA }\end{array}$ & 55 & 2 & 2 & 100 & 1.80 & 0.45 & 0.64 & 0.41 & 0.70 \\
\hline SSR54 & $\begin{array}{l}\text { F: CGAAAAGGAAACTCAACAAC } \\
\text { R: TGAACCTTATTTTCCTCGTG }\end{array}$ & 55 & 2 & 2 & 100 & 1.39 & 0.27 & 0.44 & 0.27 & 0.57 \\
\hline SSR56 & $\begin{array}{l}\text { F: GGCAACTTCGTAATTTCCTA } \\
\text { R: TGAGTAAAAGTGGGGTCTGT }\end{array}$ & 55 & 2 & 2 & 100 & 1.50 & 0.33 & 0.51 & 0.33 & 0.62 \\
\hline SSR63 & $\begin{array}{l}\text { F: GTGTTTGAAAGGGACTGTGT } \\
\text { R: CTTCATCAAAACCATGCAG }\end{array}$ & 55 & 2 & 2 & 100 & 1.84 & 0.46 & 0.65 & 0.46 & 0.67 \\
\hline SSR78 & $\begin{array}{l}\text { F: CTCCGACAATTCAAGAAAAG } \\
\text { R: CACCCAATCAAGCTATGTTA }\end{array}$ & 55 & 2 & 2 & 100 & 1.13 & 0.11 & 0.23 & 0.11 & 0.57 \\
\hline SSR52 & $\begin{array}{l}\text { F: AACACATCCTCATCCTCATC } \\
\text { R: ACCGGAAGCTATTTACATGA }\end{array}$ & 55 & 4 & 4 & 100 & 1.06 & 0.06 & 0.14 & 0.06 & 0.53 \\
\hline SSR64 & $\begin{array}{l}\text { F: AAGGAGGAGAAAGAGAAGGA } \\
\text { R: ATTTACTTGAGCAGCAGCAG }\end{array}$ & 55 & 3 & 3 & 100 & 1.63 & 0.33 & 0.48 & 0.33 & 0.81 \\
\hline SSR66 & $\begin{array}{l}\text { F: CACCAGAATTTCCCTTTTTG } \\
\text { R: ACTGTTGTTTGGCTTATGCT }\end{array}$ & 55 & 2 & 2 & 100 & 1.35 & 0.26 & 0.42 & 0.24 & 0.58 \\
\hline SSR89 & $\begin{array}{l}\text { F: TTTGAGTTCTTTCGTCCACT } \\
\text { R: GTATTTGGACATGGCGTTAT }\end{array}$ & 55 & 2 & 2 & 100 & 1.71 & 0.40 & 0.58 & 0.39 & 0.52 \\
\hline Total & & & 21 & 21 & - & - & - & - & - & - \\
\hline Mean & & & 2.33 & 2.33 & 100 & 1.46 & 0.27 & 0.42 & 0.27 & 0.62 \\
\hline
\end{tabular}

${ }^{*} \mathrm{At}=$ annealing temperature; $\mathrm{T}=$ total bands; $\mathrm{P}=$ polymorphic bands; $N_{\mathrm{E}}=$ effective number of alleles (Kimura and Crow, 1964); h = Nei's (1973) gene diversity; I = Shannon's information index (Lewontin, 1972); Ht = heterogeneity; $\mathrm{PIC}=$ polymorphism information contents

The gene diversity ranged from 0.06 (for SSR52) to 0.46 (for SSR63), with a mean value of 0.27 among the 66 varieties. The Shannon's information index (Lewontin, 1972) for the SSR markers ranged from 0.14 (for SSR52) to 0.65 (for SSR63). The highest PIC value was 0.81 for the SSR64 primer, whereas the lowest PIC value was 0.52 for SSR89, with an average value of 0.62 per locus (Table 3 ). The lowest genetic distance $(D=0.000)$ was obtained between the pairs TR47-1-TR20-2, TR55-1-TR37-1, TR17-1-TR35-1, TR01-3-TR63-1, TR20-1-TR35-2, TR632-TR63-3, Cajun Queen-Dixie Spineless-DLGG, Vaishali Badhu-Arka Anamika-Parbhani KrantiPSM-Selection2-T13, while the highest distance coefficient was obtained between the CyprusTR54-1 ( $\mathrm{D}=0.889$ ) and TR70-1-1159 Togo-1051 Togo, UGA Red Okra-1051 Togo (0.842) pair based on SSR analysis. Cluster analysis was used to group all accessions to construct an UPGMA dendrogram based on SSR data (Figure 3). This analysis divided all the accessions into four different groups. The number of okra accessions in split A, B, C, and D were 2, 18, 22, and 24, respectively. Each group was further divided into different subgroups.

\section{Combined (retrotransposons + SSR) analysis for structure}

The population structure and the inference of admixture ancestry were assessed with a model-based clustering method implemented in STRUCTURE 2.1, using $\triangle \mathrm{K}$ criterion (Evanno et al., 2005). In the STRUCTURE analysis, the $\mathrm{K}$ varied from 1 to 10 . Two differentiated gene pools were identified at the preliminary level among the 66 okra accessions, based on a combined data set of iPBS retrotransposons and SSR analysis (Figures 1 and 4). 


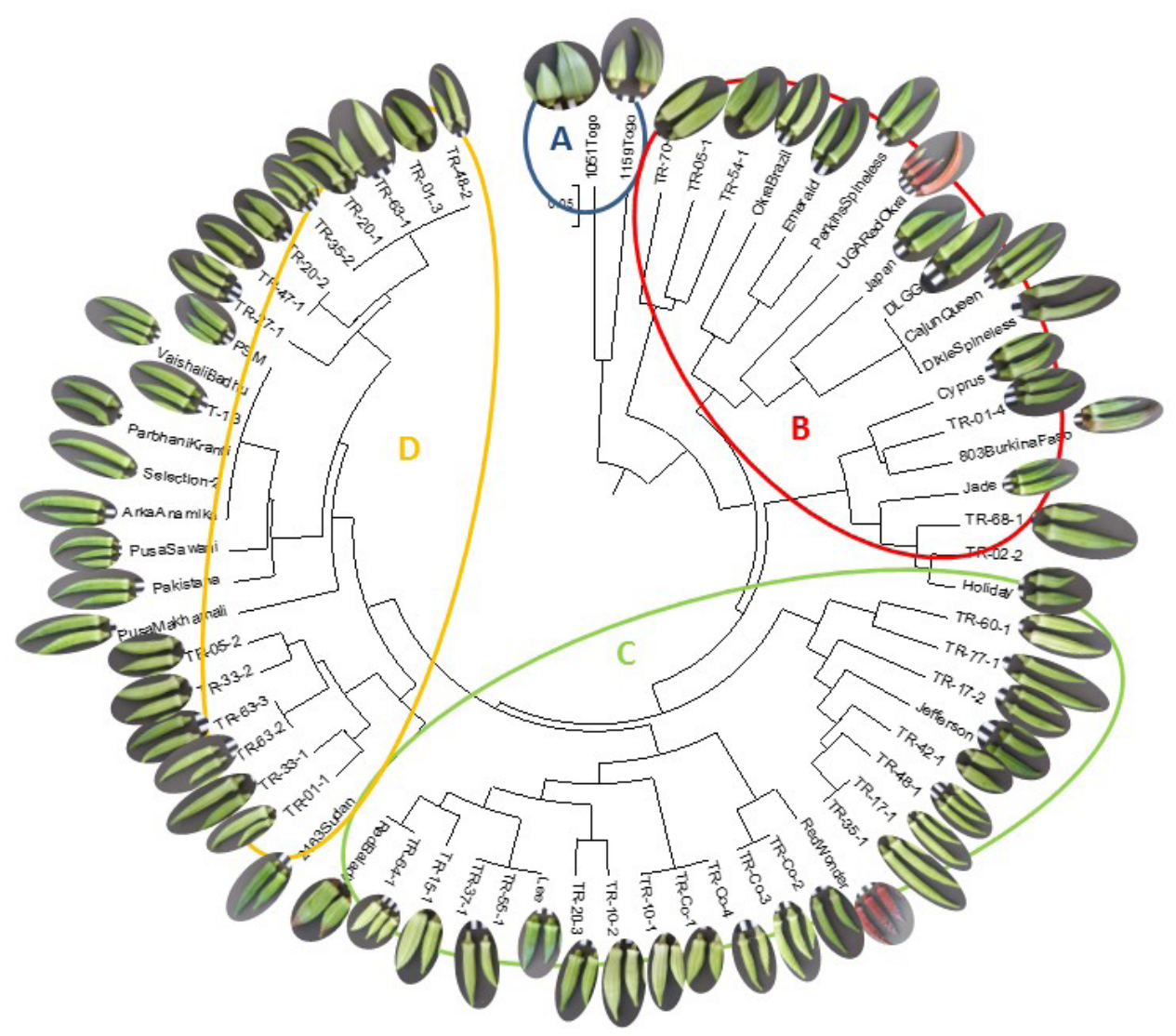

Figure 3. Neighbor-joining analysis of 66 okra landraces and cultivars based on SSR markers.

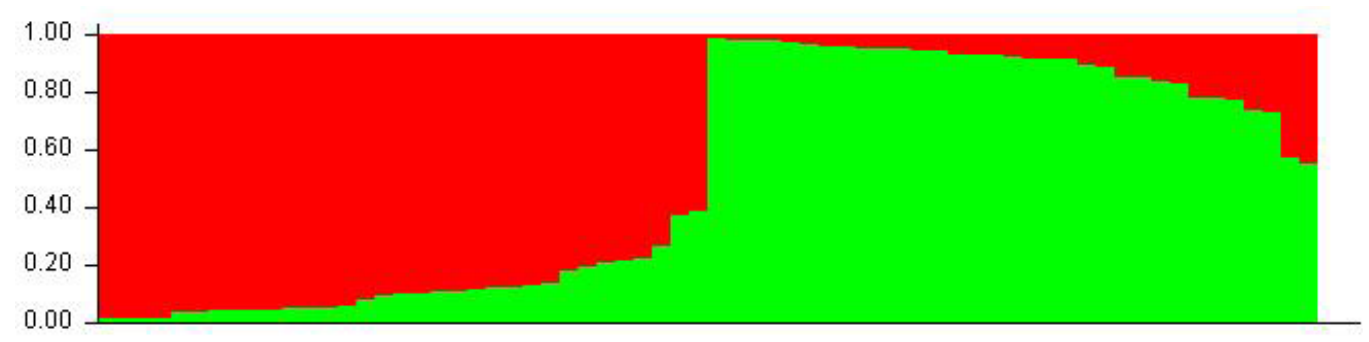

Figure 4. Population structure of 66 okra accessions used in the study, estimated population structure at $\mathrm{K}=2$.

\section{DISCUSSION}

Plant genome analysis in many crop species, including okra, has demonstrated that genetic relationships among different varieties/species can be established using different marker systems that can vary significantly. Various marker technologies may amplify different genomic regions. In the present study, we used two different marker systems (iPBS-retrotransposon and 
SSR markers). These markers differ in the nature of the evolutionary mechanism underlying their variation and distribution in the plant genome. iPBS-retrotransposon is a dominant marker system, while SSR markers are co-dominant in nature. Apart from their evolutionary difference, the results obtained from both the markers are highly correlated.

We had previously characterized 60 okra accessions based on their phenotypic traits and SRAP DNA markers. Nineteen SRAP primer combinations used for molecular characterization of okra germplasm produced 92 bands, of which 29 (31.5\%) were polymorphic among the okra accessions (Yildiz M, Ekbiç IE, Duzyaman E, Serçe S and Abak K, unpublished results). We observed high phenotypic diversity among okra accessions. However, despite the apparent phenotypic diversity in Turkish okra germplasm, lack of genetic diversity was indicated by molecular markers. Activation of transposon elements could be a probable phenomenon behind genomic plasticity. Therefore, we hypothesized that retrotransposons might be used as polymorphic markers in okra germplasm. Transposable elements, particularly the retrotransposons, constitute much of the plant genomes; their replication generates genomic diversity and makes them an excellent source of molecular markers (Schulman et al., 2004). It is well known that many transposon marker systems working in one species may not be useful in another. However, the recently developed iPBS markers are referred to as "universal retrotransposon markers", and could be utilized in all plant and animal species (Kalendar et al., 2010). These markers have been used in different crops such as chickpea, lentil, rice, and wheat.

Though universal, iPBS primers have been used to investigate genetic diversity in a few plants only. These studies revealed the applicability of iPBS-retrotransposon marker system for identification of diversity in plants. However, iPBS-retrotransposon marker system has not been used for molecular characterization and investigation of genetic diversity of okra genotypes. Our study is the first application of iPBS markers for fingerprinting and distinguishing a large number of okra genotypes. Marker systems used for molecular characterization and genetic diversity evaluation of okra genotypes should be reproducible and should have the ability to distinguish large numbers of closely related genotypes. In the present study, the band profiles produced by iPBS-retrotransposon marker system remained unchanged in PCR replications. Eighty-eight scorable bands were produced by 13 iPBS primers with 35 bands being polymorphic. The average polymorphism was $40.2 \%$ per primer. The average number of bands per primer was less (6.8 vs 9.7) than that obtained using 13 RAPD primers among 93 okra accession from Africa and Asia (Aladele et al., 2008). The higher number of bands in the above study was due to the interspecific diversity of two species. The mean PIC values of iPBS primers varied from 0.12 to 0.99 . However, polymorphism detected by retrotransposon markers was very low compared to that obtained by SSR markers. All the 9 SSR markers used in our study demonstrated $100 \%$ polymorphism. However, comparably lower (12\%) polymorphism was observed using 33 AFLP primer combinations (Kyriakopoulou et al., 2014). Because of its polymorphism capacity, technical simplicity, speed, and reproducibility, the iPBS marker system appears to have potential for fingerprinting and identification of genetic similarity of large number of okra genotypes.

Variety identification of okra is still based on morphological characters in Turkey. Most morphological characters for variety identification are multigenic and are affected by environmental conditions. In addition, different developmental stages of okra are required to assess these morphological traits making the okra variety identification time-consuming, less suitable for expeditious results, and ineffective for large number of genotypes. The okra breeders of Turkey require a rapid, robust and reliable tool for variety identification. Fingerprinting by DNA markers is 
beneficial for breeders, seed producers, and growers for protection of their own varieties, checking purity, and for identification of a variety. Among different DNA marker systems such as SSR and AFLP, the iPBS marker system has advantages such as minimal requirement for laboratory equipment, technical simplicity, speed, and availability of universal primers. Thus, the iPBS marker system can potentially be used for the identification of okra varieties. Therefore, we used this system for molecular characterization of 66 registered okra varieties of Turkey, including those introduced from foreign countries that are commonly used in okra breeding program in Turkey.

It is crucial to know the type of marker other than SSR that can provide reliable estimates of diversity and effectively identify okra varieties. To study the potential of both markers in detecting genetic polymorphism among different okra varieties, gene diversity, Shannon's information index, and the PIC values were calculated. Gene diversity and Shannon's information index of retrotransposon markers were lower than that of SSR markers, which demonstrated that microsatellites are more powerful markers for the identification of a variety. The values of genetic diversity, Shannon's information index, and PIC in our study were comparable with those reported by Yuan et al. (2014) using ISSR markers. PIC value reflects the level of genetic diversity in a population. It provides a better estimate of diversity than the raw number of alleles, because it takes into account the relative frequencies of each allele present. In our study, the average PIC value measured with retrotransposon markers was 0.66 and it ranged from 0.12 to 0.99 , whereas the average PIC value with SSR markers was 0.62 with a range from 0.52 to 0.81 . The range of PIC values obtained with SSR markers was higher than that for retrotransposons, indicating the discriminatory power of iPBS-retrotransposon markers. However, the average PIC value of retrotransposons was slightly higher than SSR markers demonstrating the ability of retrotransposons markers to differentiate between the different accessions. The average PIC value based on SSR data obtained in this study was comparable to those from other okra genetic diversity studies, but was higher than that $(P I C=0.49)$ reported in studies on 65 okra accessions using 19 SSRs (Schafleitner et. al., 2013).

Pairwise genetic distance coefficients were used to deduce phylogenetic relationships among the 66 okra varieties, based on the iPBS-retrotransposon and SSR markers, respectively (Figures 2 and 3). UPGMA clustering divided all the okra varieties into four main groups (A, B, C, and D) based on retrotransposon and SSR analysis. Group A consisted of 4 varieties with one each from Turkey and India and 2 from Africa. African varieties Red Balady and 803 Burkina Faso possessed anthocyanin in the fruit stem and tip of pod and showed close similarity in the cluster analysis. Some morphological studies suggest that Turkish okra germplasm resembles the African and, to a lesser extent, the Indian germplasm (Ariyo, 1987; Düzyaman and Vural, 2002; Düzyaman, 2005). Group B consisted of 11 varieties, all from Turkey. Group C consisted of 24 varieties. Among these 24 varieties, 6 were from Turkey while the rest were the varieties introduced in Turkey from different countries. Group D consisted of rest of the 27 varieties, most of which were from Turkey, 4 were from the USA and 1 was from India. UGA Red Okra and Red Wonder, the two varieties from the USA, clustered together and formed a subgroup in the group $D$. These varieties have red fruit and demonstrate close genetic similarity. UGA Red was bred at the University of Georgia and Red Wonder was its parent (Corley, 1985). It is obvious from the Figure 2 that most of the varieties with same fruit color were clustered together indicating that retrotransposon markers might have association with fruit color. It is evident that varieties with the same origin were clustered together, illustrating the utility of iPBS-retrotransposon markers in cultivar identification and genetic diversity studies. In contrast, in the phylogenetic analysis of lentil and pea using iPBS-retrotransposon 
markers, it was observed that landraces from the same geographical region were often placed in different clusters, indicating that grouping based on genetic parameters was not closely related to the geographic origin (Baloch et al., 2015a,b). Our study demonstrates that iPBS-retrotransposons can be successfully used for establishing the phylogenetic relationship.

To check the reliability of iPBS-retrotransposon markers, we used some SSR markers to check the clustering pattern of the same okra varieties. Surprisingly, the 9 SSR markers used to reveal the phylogenetic relationship, also divided the selected okra accessions into four groups, $A$, $B, C$, and D. Turkish germplasm differed from that of the foreign landraces and mainly clustered into two main groups, $\mathrm{C}$ and $\mathrm{D}$. This classification appeared to relate to the distinct geographical regions from which the genotypes were obtained. Group A harbored 2 African varieties, 1051 Togo and 1159 Togo. 1051 Togo is a robust okra line from West Africa with broad leaves and thick fruits and has also been found as a distinct line in many other studies (Hamon and Charrier, 1983; Hamon and Noirot, 1991; Düzyaman and Vural, 2002; Yildiz M, Ekbiç IE, Duzyaman E, Serçe $S$ and Abak K, unpublished results). These two varieties were introduced in Turkey and used in breeding programs by different researchers. Group B possessed 18 varieties mostly from the USA, 2 from Japan, and 6 from Turkey. Group C comprised of 22 varieties mostly from Turkey, including 4 foreign varieties. Group D consisted of the rest 24 okra varieties, including 15 from Turkey, 9 from India, and 1 from Africa. We acknowledge that the number of SSR markers used by us was very low for confidently revealing the genetic diversity. At least 30 SSR markers are required for the estimation of genetic relationship among varieties. However, our purpose here was to simply compare the results and to check the utility of iPBS-retrotransposons in comparison with the SSR markers. Though we used very low number of SSR markers, the SSR-based cluster analysis was more prominent in clustering landraces on the basis of their provenance, illustrating the efficiency of SSR markers over iPBS-retrotransposons. All Indian varieties were placed together in group D, while all accessions from the USA were positioned in group B (Figure 3). Similarly, some commercially released varieties such as TR-CO-2, TR-CO-3, TR-CO-4, and TRCO-01 were highly similar and were clustered together. Most probably, these commercial cultivars harbored same parents in their pedigree. Many accessions from the same geographical provinces were grouped under the same cluster. Grouping of accessions based on geographical regions demonstrated the preferences of some particular varieties in the same geographical regions by the consumers. However, a phenotypic study of 585 okra accessions from all over the world (including 113 accessions from Turkey) failed to find common distinguishing characteristics at the country level for Turkish, Indian, Iranian, and Yugoslavian germplasm (Martin et al., 1981).

The estimated membership fractions of all of the accessions are presented in Figure 4. The population structure analysis revealed two subpopulations (Figure 4). The structure analysis revealed that all the varieties used in this study were derived from two subpopulations, showing that the diversity harbored by Turkish okra is very low, which is in agreement with the neighborjoining analysis. Only a few varieties were used as parent lines in the Turkish okra improvement program. Therefore, renewed emphasis should be placed on new sources of germplasm in the breeding pool to widen genetic diversity and allow continued progress in developing elite varieties. In future, parent selection for crossing should consider genotypes with greater genetic distance and avoid those with common background. Introduction of plants should be made from countries having greater genetic diversity for this crop.

In conclusion, the present study used the iPBS-retrotrasposon marker system to generate pre-breeding data that can potentially be applied for selection of appropriate parents to introduce 
greater genetic variation in okra breeding programs and help the breeders of Turkey. The DNA fingerprinting data generated in the study could also be used for variety description in the future. This study demonstrates that the iPBS marker system is a powerful and easy method for fingerprinting and distinguishing okra genotypes.

\section{Conflicts of interest}

The authors declare no conflict of interest.

\section{ACKNOWLEDGMENTS}

Research supported by the Scientific Research Projects Unit of Yuzuncu Yil University, Van, Turkey (\#2014-ZF-B206). We would like to express our gratitude to the Aegean Agricultural Research Institute, Izmir, Turkey (AARI) for providing seed samples.

\section{REFERENCES}

Aladele SE, Ariyo OJ and Lapena R (2008). Genetic relationships among West African okra (Abelmoschus caillei) and Asian genotypes (Abelmoschus esculentus) using RAPD. Afr. J. Biotechnol. 7: 1426-1431.

Andeden EE, Baloch FS, Derya M, Kilian B, et al. (2013). iPBS-Retrotransposons-based genetic diversity and relationship among wild annual Cicer species. J. Plant Biochem. Biotechnol. 22: 453-466.

Ariyo OJ (1987). Multivariate analysis and the choice of parents for hybridization in okra (Abelmoschus esculentus (L.) Moench. Theor. Appl. Genet. 74: 361-363.

Baloch FS, Derya M, Andeden EE, Alsaleh A, et al. (2015a). Inter primer binding site (iPBS) retrotransposon and ISSR diversity among wild lens species. Biochem. Syst. Ecol. 58: 162-168.

Baloch FS, Alsaleh A, Sáenz de Miera LE, Hatipoğlu R, et al. (2015b). DNA based iPBS-retrotransposon markers for investigating the population structure of pea (Pisum sativum) germplasm from Turkey. Biochem. Syst. Ecol. 61: $244-252$.

Baránek M, Mészáros M, Sochorová J, Čechová J, et al. (2012). Utility of retrotransposon-derived markers systems for differentiation of presumed clones of the apricot cultivar Velkopavlovická. Sci. Hort. 143: 1-6.

Bates DM (1968). Notes on the cultivated Malvaceae. 2. Abelmoschus Baileya 16: 99-112.

Boiteux LS, Fonseca MEN and Simon PW (1999). Effects of plant tissue and DNA purification methods on randomly amplified polymorphic DNA-based genetic fingerprinting analysis in carrot. J. Am. Soc. Hortic. Sci. 124: 32-38.

Charrier A (1984). Genetic resources of the genus Abelmoschus Med. (Okra). IBPGR Secretariat, Rome.

Corley WL (1985). UGA red okra: A new edible ornamental. Univ. Ga. Agr. Expt. Sta. Res. Rpt.

De Candolle A (1886). Origin of cultivated plants. Hather, New York.

De Riek J, Calsyn E, Everaert I, Van Bocksteal E, et al. (2001). AFLP based alternative for the assessment of the distinctness, uniformity and stability of sugar beet varieties. Theor. Appl. Genet. 103: 1254-1256.

Düzyaman E (1997). Okra: botany and horticulture. Hortic. Rev. 21: 41-72.

Düzyaman E (2005). Phenotypic diversity within a collection of distinct okra (Abelmoschus esculentus) cultivars derived from Turkish land races. Genet. Resour. Crop Evol. 52: 1019-1030.

Düzyaman E (2009). Okra in Turkey domestic landraces. In: Okra Handbook Global Production, Processing, and Crop Improvement (Dhankhar BS and Singh R, eds.). HNB Publishing, New York, 475: 323-346.

Düzyaman E and Vural H (2002). Different approaches in the improvement process of local okra varieties. Acta Hortic. 579: 139-144.

Evanno G, Regnaut S and Goudet J (2005). Detecting the number of clusters of individuals using the software STRUCTURE: A simulation study. Mol. Ecol. 14: 2611-2620.

Finnegan DJ (1989). Eukaryotic transposable elements and genome evolution. Trends Genet. 5: 103-107.

Grubben GJH (1977). Tropical vegetables and their genetic resources. International Board for Plant Genetic Resources, Rome, FAO.

Gulsen O, Karagul S and Abak K (2007). Diversity and relationships among Turkish okra germplasm by SRAP and phenotypic marker polymorphism. Biologia 62: 41-45.

Guo DL, Guo MX, Hou XG and Zhang GH (2014). Molecular diversity analysis of grape varieties based on iPBS markers. 
Biochem. Syst. Ecol. 52: 27-32.

Hamon S and CharrierA (1983). Large variation of okra collected in Benin and Togo. Plant Genet. Resour. Newsl. 56: 52-58.

Hamon S and Noirot M (1991). Some proposed procedures for obtaining a core collection using quantitative plant characterization data. International workshop on okra genetic resources held at the National Bureau for Plant Genetic Resources.International Crop Network Series No. 5, 89-94.

Iremiren GO, Osara AW and Okiy DA (1991). Effects of age of harvesting after pod set on the growth, yield and quality of Okra (Abelmoschus esculentus). Exp. Agric. 27: 33-37.

Jaccard P (1908). Nouvelles recherchers sur la distribution florale. Bull. Soc. Vaud. Sci. Nat. 44: 233-270.

Kalendar R, Antonius K, Smykal P and Schulman AH (2010). iPBS: a universal method for DNA fingerprinting and retrotransposon isolation. Theor. Appl. Genet. 121: 1419-1430.

Kimura M and Crow JF (1964). The number ofallelesthatcanbemaintened in a finitepopulation. Genetics 49: 725-738.

Kyriakopoulou OG, Arens P, Pelgrom KTB, Karapanos I, et al. (2014). Genetic and morphological diversity of okra (Abelmoschus esculentus [L.] Moench.) genotypes and their possible relationships, with particular reference to Greek landraces. Sci. Hort. 171: 58-70.

Lewontin RC (1972). Testing the theory of natural selection. Nature 236: 181-182.

Martin FW, Rhodes AM, Ortiz M and Diaz F (1981). Variation in okra. Euphytica 30: 697-705.

Nei M (1973). Analysis of gene diversity in subdivided populations. Proc. Natl. Acad. Sci. U. S. A. 70: 3321-3323.

Nwangburuka CC, Kehinde OB, Ojo DK, Denton OA, et al. (2011). Morphological classification of genetic diversity in cultivated okra Abelmoschus esculentus (L.) Moench using principal component analysis (PCA) and single linkage cluster analysis (SLCA). Afr. J. Biotechnol. 10: 11165-11172.

Prakash K, Pitchaimutu M and Ravishankar KV (2011). Assessment of genetic relatedness among okra genotypes [Abelmoschus esculentus (L.) Moench] using RAPD markers. Elec. J. Plant Breed. 2: 80-86.

San Miguel P, Tikhonov A, Jin YK, Motchoulskaia N, et al. (1996). Nested retrotransposons in the intergenic regions of the maize genome. Science 274: 765-768.

Sawadogo M, Ouedraogo JT, Balma D, Ouedraogo M, et al. (2009). The use of cross species SSR primers to study genetic diversity of okra from Burkina Faso. Afr. J. Biotechnol. 8: 2476-2482.

Schafleitner R, Kumar S, Lin C, Hegde SG, et al. (2013). The okra (Abelmoschus esculentus) transcriptome as a source for gene sequence information and molecular markers for diversity analysis. Gene 517: 27-36.

Schulman AH, Flavell AJ and Ellis THN (2004). The application of LTR retrotransposons as molecular markers in plants. Methods Mol. Biol. 260: 145-173.

Yeh FC, Yang R, Boyle TJ, Ye Z, et al. (2000). Pop Gene32, Microsoft windows-based freeware for population genetic analysis. Version1.32. Molecular biology and Biotechnology Centre, University of Alberta, Edmonton.

Yuan CY, Zhang C, Wang P, Hu S, et al. (2014). Genetic diversity analysis of okra (Abelmoschus esculentus L.) by inter-simple sequence repeat (ISSR) markers. Genet. Mol. Res. 13: 3165-3175.

Zampicinini G, Blinov A, Cervella P, Guryev V, et al. (2004). Insertional polymorphism of a non-LTR mobile element (NLRCth1) in European populations of Chironomus riparius (Diptera, Chironomidae) as detected by transposon insertion display. Genome 47: 1154-1163. 